Acta Protozool. (2017) 56: 217-220

www.ejournals.eu/Acta-Protozoologica

doi:10.4467/16890027AP.17.019.7500

PROTOZOOLOGICA

Short communication

\title{
Observations of Apparent Lorica Variability in Salpingacantha (Ciliophora: Tintinnida) in the Northern Pacific and Arctic Oceans
}

\author{
John R. DOLAN ${ }^{1}$, Eun Jin YANG \\ ${ }^{1}$ Sorbonne Universités, UPMC Université Paris 06, CNRS UMR, Laboratoire d'Océanographie de Villefranche-sur-Mer, Station \\ Zoologique, Villefranche-sur-Mer, France; ${ }^{2}$ Department of Polar Ocean Environment, Korea Polar Research Institute, Yeonsu gu, \\ Incheon, South Korea
}

\begin{abstract}
Species identifications of tintinnid ciliates are based on characteristics of the lorica housing the ciliate cell. Molecular characterization of tintinnid ciliates has revealed the occurrence of cryptic species, genetically distinct forms with similar loricas, as well as polymorphic species in which genetically identical forms have distinct loricas. Among this latter category may be forms currently recognized as species of the genus Salpingacantha, erected by Kofoid and Campbell for forms originally described as varieties of species of Salpingella with 'teeth' on the margin of the lorica oral opening. Some workers have expressed the opinion that the genus is artificial and notably a recent molecular study suggested that Salpingella and Salpingacantha are likely synonyms. In this short communication we report on finding morphologically distinct loricas (containing ciliate cells) of Salpingacantha in single samples from stations in the North Pacific and Arctic Oceans in 2010, 2015 and 2016. We found up to 5 distinct Salpingacantha forms co-occurring, often with abundant Salpingella acuminata populations suggesting that some Salpingacantha species may be varieties of Salpingella acuminata. While we lack genetic data needed for definitive proof of polymorphism, here we document remarkable gradual gradients in morphology suggestive of polymorphism.
\end{abstract}

Keywords: microzooplankton, plankton, polymorphism, tintinnida.

\section{INTRODUCTION}

The genus Salpingacantha was created by Kofoid and Campbell (1929) separating forms previously considered as varieties of Salpingella which had 'teeth' on the oral margin ( $S$. undata, S. simplex, S. unguiculata) as well 4 'new' forms, with teeth more or less evident

\footnotetext{
Address for correspondence: John R. Dolan, Sorbonne Universités, UPMC Université Paris 06, CNRS UMR 7093, Laboratoire d'Océanographie de Villefranche-sur-Mer, Station Zoologique, 06230 Villefranche-sur-Mer, France (dolan@obs-vlfr.fr; Tel.: +330493763834
}

on the oral margins, that they described from the Agassiz Expedition ( $S$. ampla, S. crenulata, S. exilis, $S$. perca). In their revision of 1939, Kofoid and Campbell state "Closely resembles Salpingella but differs from it in that the oral margin is toothed or has at least the first phases in the formation of teeth, as in perca, in which they are mere minute marginal extensions of longitudinal folds". With regard to Salpingcantha simplex, their description 1929 states "... collar scarcely flaring, without definite teeth, its margin undulating...". Thus although 'teeth' on the oral margin supposedly distinguish the genus Salpingcantha, exactly what constitutes 'teeth' is unclear. Furthermore, the appearance (or 
not) of 'teeth' could depend on small changes in the orientation of a specimen or small deformations in the oral margin.

A recent revision of tintinnid taxonomy based on molecular data suggests that Salpingacantha is likely a synonym of Salpingella (Santoferrara et al. 2017). The observation was based on findings that the SSU rDNA sequences of two forms corresponding with the morphologies described for Salpingacantha undata and $S$. unguiculata were intermingled among sequences attributed to Salpingella acuminata. Their opinion of synonomy is not new. Over the years various authors have opined that given the overall similarities in lorica morphology, Salpingacantha is probably a synonym of Salpingella (e.g., Travers and Travers 1973; Cordeiro and Sassi 1997; Alder 1999). In fact, Cordeiro and Sassi (1997) provided a series of micrographs illustrating a remarkable gradient of morphologies ranging from Salpingella acuminata to Salpingacantha undata. However, most of the specimens were empty lorica and different lorica were from different samples. It is important to distinguish empty lorica from those containing ciliate cells. Empty lorica are known to persist in the water column, can become degraded or distorted, and have wider geographic distributions than the living cells (Kato and Taniguchi 1993). Empty lorica are then unreliable indicators of living ciliates. Evidence of the co-occurrence of live forms of distinct Salpingacantha appears to be lacking and provided the impetus for this short report. Here we report on the co-occurrence of apparent morphological variants in Salpingacantha in samples gathered in the summer from 2010 to 2016 in the North Pacific and Arctic Oceans.

\section{METHODS AND MATERIALS}

Samples were collected from onboard the Korean Research Icebreaker Araon in August/early September from 2010 to 2016. Sampling dates and station locations of samples considered in this report are given in the supplementary data file. Plankton net tows were performed to assess microplankton community composition. Net tows were made using a $20-\mu \mathrm{m}$ plankton net of $0.45 \mathrm{~m}$ diameter usually towed from $100 \mathrm{~m}$ depth to the surface (water column depth permitting). Net tow material was fixed by standard methods $(6 \%$ Bouin's or 2\% Lugol's, final concentration). Aliquots were examined in settling chambers. Specimens correctly oriented for diagnosis were enumerated and photographed using an Olympus IX71 microscope equipped with DIC optics and a DP71 camera interfaced with a PC running Olympus BioCell image analysis software with scale calibration (Olympus France SAS). In the text the sample origins are indicated in parentheses in bold indicating year and station.
The location coordinates and sampling dates appear in the supplementary data file. Tintinnid "species" identifications based on lorica morphology refer to the designations found in the monographs of Kofoid and Campbell (1929, 1939).

\section{RESULTS AND DISCUSSION}

On several occasions we found a variety of different Salpingacantha forms within single samples. Salpingacantha were generally, but not always, found in presence of Salpingella acuminata. In one sample (2015 St 5) we found 5 morpho-types representing a clear gradient from Salpingella acuminata to Salpingacantha undata (Fig. 1). As the length of the outward sloping teeth alters greatly lorica opening diameter (LOD), the forms differed considerably in LOD, ranging from $18 \mu \mathrm{m}$ for the crenulated oral margin form (Fig. 1c) to the '4-toothed' with an LOD of $27 \mu \mathrm{m}$ (Fig. 1f). Notably in two samples Salpingacantha were found in the absence of Salpingella. Figure 2 shows 5 different morpho-types found in a sample (2016 St 29) in which no typical Salpingella acuminata were found.

Different morpho-types of Salpingacantha dominated different samples with no apparent pattern. The numbers and dimensions of the different morpho-types in individual samples is given in the supplementary data file. Among specimens of Salpingacantha there was relatively little variability in overall length but distinct differences in the diameter and shape of the lorica oral opening. We suggest that the co-occurrence with Salpingella acuminata and the large gradient in architecture of the lorica oral opening of Salpingacantha raises the possibility that "species" of Salpingacantha may be varieties of Salpingella species.

Salpingacantha and Salpingella are "cosmopolitan" genera (Pierce and Turner 1993), both widely (and coincidentally) distributed (Dolan and Pierce 2013, Fig. 10.3). However, Salpingella species are found much more commonly than Salpingacantha. A quick search using Google Scholar (https://scholar.google.com) for publications containing the term 'Salpingella' yields about 500 publications whereas the term 'Salpingacantha' returns about 50. Most (but not all) reports of the occurrence of Salpingacantha species also report the occurrence of Salpingella.

There has never been a consensus with regard to whether or not Salpingacantha are morpho-types of Salpingella or distinct species. Early on Jörgensen, in creating the genus Salpingella (Jörgensen 1924), con- 


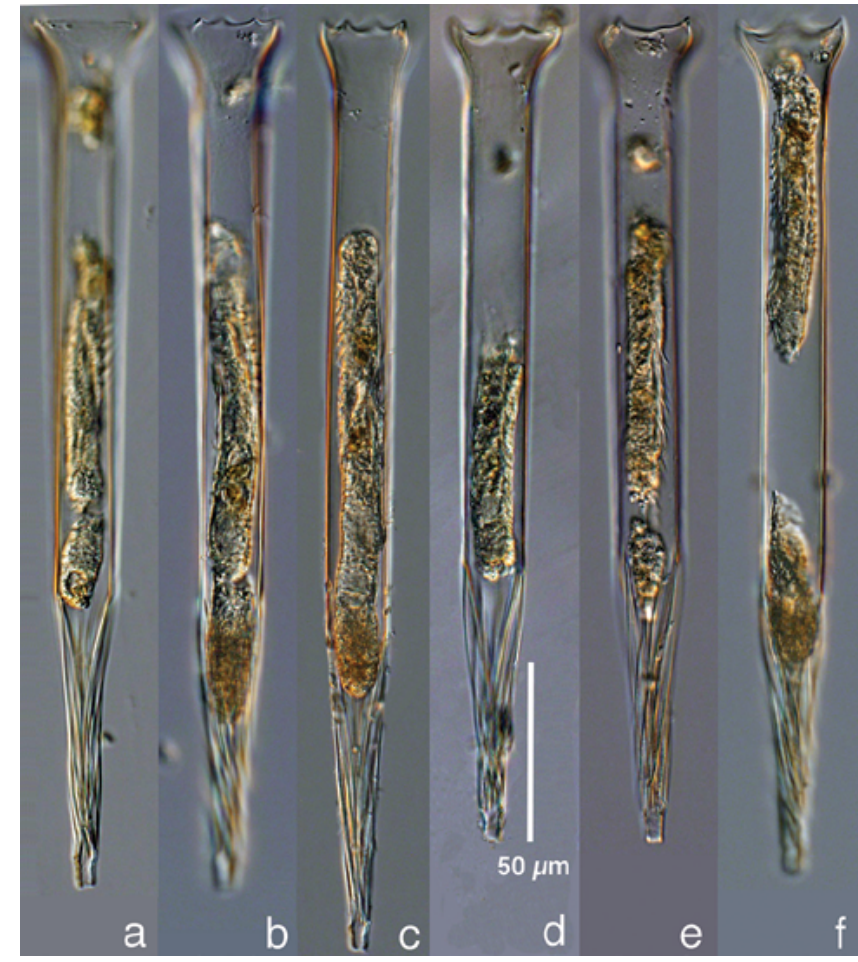

Fig. 1. Varieties of Salpingacantha from a 2015 sample in the Chukchi Sea (2015 St 5). In the sample, typical Salpingella acuminata ("a") were dominant with 70 cells found for the 15 Salpingacantha cells encountered. The "b" most closely corresponds with $S$. crenulata, "c" and "d" with S. perca, "e" with S. unguiculata and "f" with $S$. ampla. Note that form "e", if rotated $45^{\circ}$, could easily be mistaken for Salpingella acuminata.

tended that Salpingella acuminata with "teeth" were an artifact, perhaps mounting media distorts a relatively flexible oral margin; he disputed Brandt's designation of toothed forms as separate species (Brandt 1906). Kofoid and Campbell (1939: 394) discounted Jörgensen's view that the 'teeth' were an aberration or an artifact. However, they admitted that in their samples Salpingella usually occurred with Salpingacantha and furthermore that Salpingacantha usually occurred as a small number of individuals.

It is perhaps significant that for Kofoid and Campbell, the forms they distinguished as species of Salpingacantha represented an evolutionary series of toothed oral margin beginning with $S$. perca and culminating in S. undata as shown in Fig. 3 (Kofoid and Campbell 1939: 394). Kofoid was an avowed proponent of orthogenesis (see Kofoid 1930) and it is plausible to

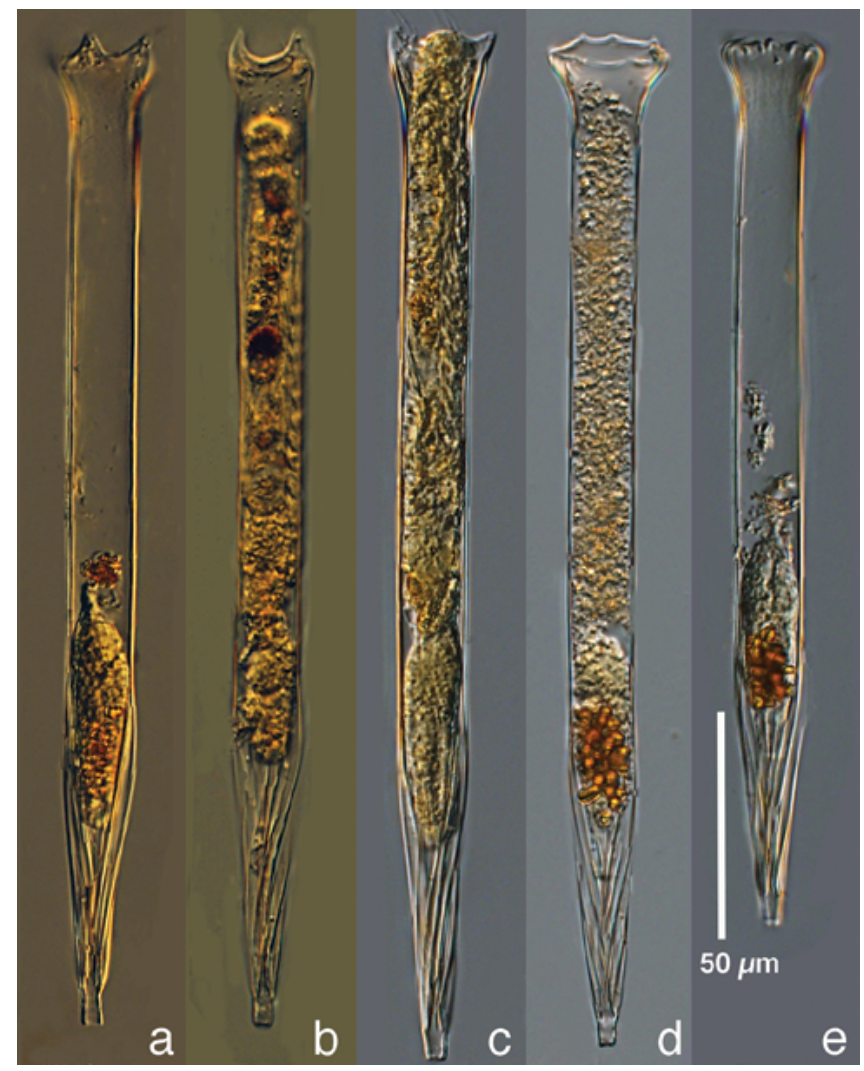

Fig. 2. Varieties of Salpingacantha from a 2016 sample in the Chukchi Sea (2016 St 29). In the sample no typical Salpingella acuminata were found. In the conspectus of Kofoid and Campbell (1929) the form "a" most closely resembles $S$. ampla, "b" S. unguiculata, "c" S. simplex, "d" S. perca, and "e" S. crenulata. Note that form "c" if rotated $45^{\circ}$ could easily be mistaken for Salpingella acuminata.

assume he was strongly pre-disposed to seeing order and directionality in diverse morphologies. Admittedly, we can be assumed to be pre-disposed to assuming that tintinnid species can exhibit more or less distinct morphologies. We have previously found polymorphism in Cymatocylis (Kim et al. 2012) with different morpho-types not clearly associated with environmental conditions but rather multiple morpho-types found when population density is high (Dolan et al. 2013). Obviously, a definitive answer with regard to Salpingacantha awaits single-cell sequencing to diagnose the genetic identity of all the diverse morpho-types we and others (Cordeiro and Sassi 1997) have encountered.

Acknowledgements. Financial support was provided by the CNRS (France) and the project 'K-AOOS (KOPRI, PM17040)' funded by the MOF(Korea). We gratefully acknowledge the helpful comments of a constructive reviewer. 


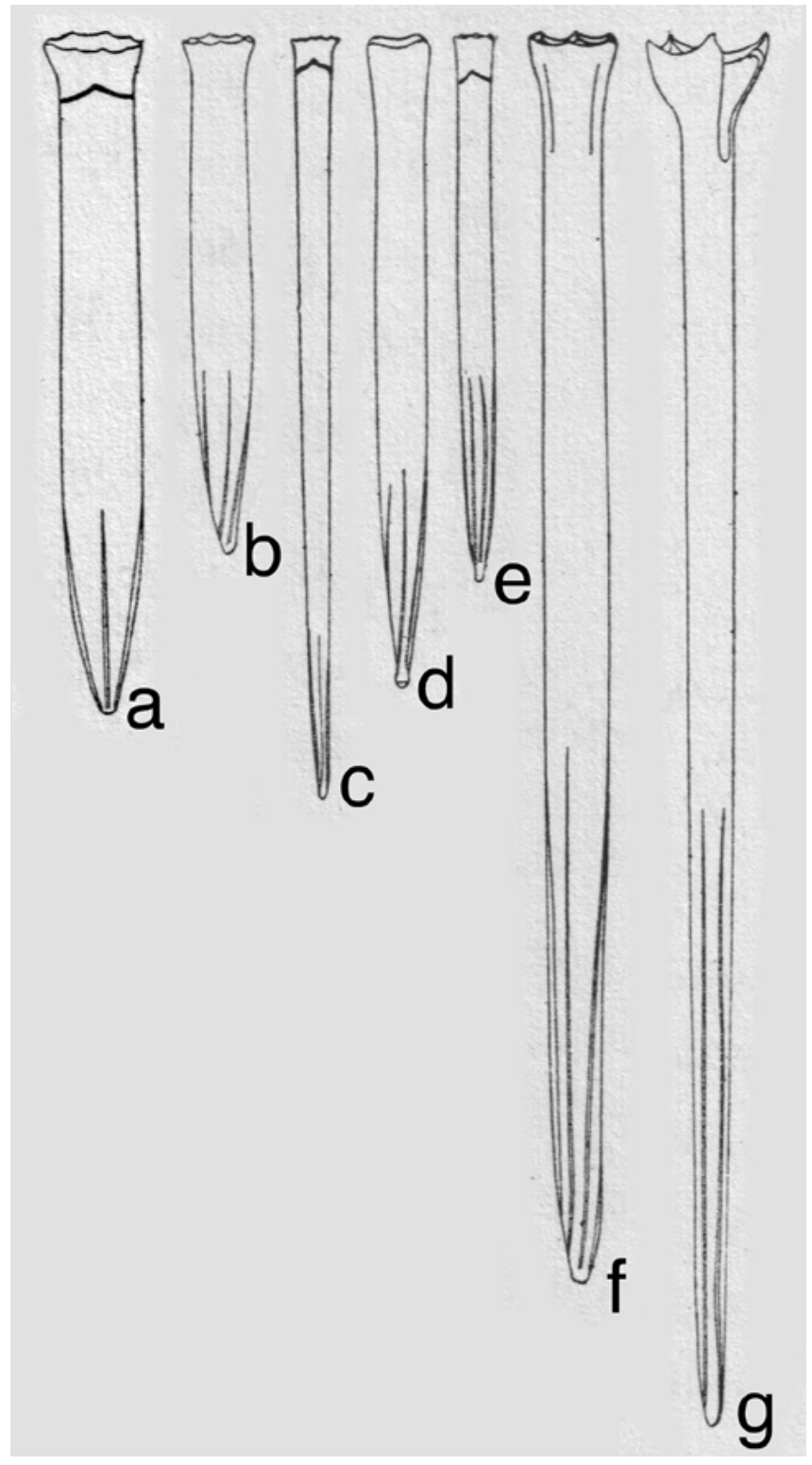

Fig. 3. The illustrations of Salpingacantha species from Kofoid and Campbell 1929 arranged as the evolutionary series given in Kofoid \& Campbell 1939 in which S. perca "presents the earliest phase in evolution of toothed oral margin": a. S. perca, b. S. crenulata, c. S. exilis, d. S. simplex, e. S. unguiculata, f. S. ampla, and g. S. undata. Note that $S$. perca, $S$. exilis, and $S$. unguiculata are depicted with a diaphragm apparatus similar to those of Salpingella (Agatha 2010).

\section{REFERENCES}

Agatha S. (2010) A light and scanning electron microscopic study of the closing apparatus in tintinnid ciliates (Ciliophora, Spirotricha, Tintinnina): a forgotten synapomorphy. J. Eukaryot. Microbiol. 57: 297-307

Alder V. A. (1999) Tintinnoinea. In: Boltovskoy D. (Ed.), South Atlantic Zooplankton. Backhuys Publishers, Leiden, 321-384

Brandt K. (1906) Die Tintinnodeen der Plankton-Expedition. Ergebnisse der Plankton-Expedition der Humboldt-Stiftung 3:L.a.

Cordeiro T. A., Sassi R. (1997) Tintinnina (Ciliophora, Protista) of the North Sea during the spring of 1986. Helgol. Meeresunt, 51: $155-172$

Dolan J. R., Pierce R. W. (2013) Diversity and distributions of tintinnids. In: Dolan J. R., Montagnes D.J.S., Agatha S., Coats D.W., Stoecker D.K. (Eds.), The Biology and Ecology of Tintinnid Ciliates: Models for Marine Plankton. Wiley-Blackwell, Oxford, 214-243

Dolan J. R., Yang E. J., Lee S. H., Kim S.Y. (2013) Tintinnid ciliates of the Amundsen Sea (Antarctica) Plankton Communities. Polar Res. 32: 19784

Jörgensen E. (1924) Mediterranean tintinnids. Report on the Danish Oceanographical Expeditions 1908-10 to the Mediterranean and adjacent Seas. 2 J.3. Biology, 1-110

Kato S., Taniguichi A. (1993) Tintinnid ciliates as indicator species of different water masses in the western North Pacific Polar Front. Fish. Oceanogr. 2: 166-174

Kim S. Y., Choi J. K., Dolan J. R., Shin H. C., Lee S., Yang E. J. (2013) Morphological and ribosomal DNA-based characterization of six Antarctic ciliate 5 morphopecies from the Amundsen Sea with phylogenetic analyses. J. Eukaryot. Microbiol. 60: 497-513

Kofoid C. A. (1930) Factors in the evolution of the pelagic ciliata, the Tintinnoinea. in: Contributions to Marine Biology, Stanford University Press, 1-39

Kofoid C. A., Campbell A. S. (1929) A Conspectus of the Marine and Freshwater Ciliata Belonging to the suborder Tintinnoinea, with Despcriptions of New Species Principally from the Agassiz Expedition to the Eastern Tropical Pacific 1904-1905. Univ. Calif. Pub. Zool. 34: 1-403

Kofoid C. A., Campbell A. S. (1939) The Tintinnoinea of the Eastern Tropical Pacific. Bull. Mus. Comp. Zoöl. Harvard Coll. 84: $1-473$

Pierce R. W., Turner J. T. (1993) Global biogeography of marine tintinnids. Mar. Ecol. Prog. Ser. 94: 11-26

Santoferrara L. F., Alder V. V., McManus G.B. (2017) Phylogeny, classification and diversity of Choreotrichia and Oligotrichia (Ciliophora, Spirotrichea). Mol. Phylo. Evol. 112: 12-22

Travers A., Travers M. (1973) Présence en Méditerranée du genre Salpingacantha Kofoid \& Campbell (Ciliés, Oligotriches, Tintinnides). Rapp. Comm. Int. Mer Médit. 21: 425-432

Received on $10^{\text {th }}$ September, 2017; revised on $8^{\text {th }}$ October, 2017; accepted on $10^{\text {th }}$ October, 2017 